\title{
Before and after of the Gurukula phenomenon
}

\author{
Jitka Schlichtsová
}

https://doi.org/10.14712/25704893.2018.2

\begin{abstract}
The article's goal is to gather information about the general idea, principles and ways of education as practiced by the International Society for Kṛṣna Consciousness (ISKCON). First, the text summarizes the foundations and theoretical concepts of ISKCON's education and compares them with the traditional Vaishnava education. Second, the article explores the historical development of Hare Kṛṣna education in the Gurukula context, explains the problem of child abuse and presents the available information about the current state of Gurukula education around the world. Finally, the text briefly mentions the Czech Gurukula project in Kršnův dvurr (1995-1997) and reconstructs the failed applications of the Czech devotees to include the Gurukula in the list of schools and educational institutions of the Ministry of Education, Youth and Sports of the Czech Republic.
\end{abstract}

Keywords: Gurukula; Hare Kṛṣna Movement; International Society for Kṛșna Consciousness; Prabhupāda; education
Abstrakt: Práce si klade za cíl především shromáždit informace o smyslu, principech a způsobech výchovy a vzdělávání $\mathrm{v}$ gurukulách Mezinárodní společnosti pro vědomí Kršny (ISKCON). V textu jsou nejprve popsána východiska a teoretické pojetí výchovy v hnutí a jeho srovnání s původním způsobem vzdělávání višnuistické tradice. Dále se práce věnuje konkrétnímu historickému vývoji a podobě vzdělávání $\mathrm{v}$ gurukulách ISKCON, problematice zneužívání dětí a přináší dostupné informace o současném stavu gurukulského vzdělávání ve světě. Práce okrajově zmiňuje I projekt Gurukula Kršnův dvůr v České republice a rekonstruuje neúspěšné snahy českých oddaných o její zařazení do sítě škol a školských zařízení Ministerstva školství, mláděže a tělovýchovy České republiky v letech 1995-1997.

Klíčová slova: gurukula; hnutí Haré Kršna; Mezinárodní společnost pro vědomí Kršny; Prabhupáda; výchova; vzdělání

Received: 29 March 2016, Accepted: 8 November 2016

Published online: 28 May 2018

Mgr. Jitka Schlichtsová, independent scholar

E-mail: jschlichtsova@gmail.com

(C) 2017 The Author. This is an open-access article distributed under the terms of the Creative

Commons Attribution License (http://creativecommons.org/licenses/by/4.0). 
The concept of primary education in the Hare Kṛṣna movement (the International Society for Kṛ̣na Consciousness, ISKCON) has only been explored very little, not only in Czech academia, but also in the international context. The most systematizing approach to this problem appears in the works of the American sociologist E. Burke Rochford (Midlebury College, Vermont), who dedicated thirty years of his life to sociological research of the Hare Krșna. A great part of his work comprises of analyses of the Gurukula education and attempts to solve its problematic aspects. He gathered a plethora of testimonies and interviews with devotees from the United States. He wrote two monographs about the social structure of the Hare Kṛșna, Hare Krishna in America (1985) and The Hare Krishna Transformed (2007). ${ }^{1}$ Rochford is also a member of the editorial board of ISKCON Communications Journal published semi-annually since 1993 by the International Society for Kṛṣna Consciousness. In this journal he published many scholarly studies about the abuse of children in the Gurukulas, which have improved our understanding of the problem and significantly contributed to worldwide scholarly discussion. ${ }^{2}$ His 1999 study "Education and Collective Identity: Public Schooling of Hare Krishna Youths" presents a kind of conclusion to his research in the Gurukula education. ${ }^{3}$ Among other publications that deal with the Gurukula theme, is a 2013 collective monograph The Hare Krishna Movement: The Postcharismatic Fate of a Religious Transplant. ${ }^{4}$

In the Czech context, the phenomenon of ISKCON's Gurukula education is seldom mentioned. The only larger work that focuses specifically on the Gurukula phenomenon is my M.A. thesis Výchova a vzdělání v hnutí Hare Kršna (Education in the Hare Krṣna movement) ${ }^{5}$ and a short article "Pán Kršna a oddané děti" ("Lord Kṛṣna and the devotee children") published in the Dingir magazine. ${ }^{6}$ Among the older Czech scholarly production, only Martin Fárek's Institucionalizace alternativního náboženství (On the institutionalization of alternative religions) dedicates some space

1 E. Burke Rochford, The Hare Krishna in America, New Brunswick, N. J.: Rutgers University Press 1985, 324 p.; E. Burke Rochford, The Hare Krishna Transformed, New York: New York University Press 2007, 285 p. Regarding the role of the family in the ISKCON, see also E. BURKE Rochford, "Family Development and Change in the Hare Krishna Movement", in James R. Lewis and Jesper Aagaard Petersen, Controversial New Religions, New York: Oxford University Press 2005, xii, p. 101-117.

2 Here I am specifically referring to the following two articles: E. BURKE RochFord, "Family Formation, Culture and Change in the Hare Krshna Movement", ISKCON Communications Journal (2/1997): p. 61-82, and E. Burke Rochford and Jennifer Heinlein, "Child Abuse in the Hare Krishna Movement: 1971-1986”, ISKCON Communications Journal (1/1998): p. 43-69.

3 E. Burke Rochford, "Education and Collective Identity: Public Schooling of Hare Krishna Youths”, in Susan Palmer and Charlotte Hardman, Children in New Religions, New Brunswick, N. J.: Rutgers University Press, 1999, p. 29-50.

4 Edwin F. Bryant and Maria Ekstrand, The Hare Krishna Movement: The Postcharismatic Fate of a Religious Transplant, New York: Columbia University Press, 2013, 496 p.

5 Jitka Schlichtsová, Výchova a vzdělání v hnutí Haré Kršna (Education in the Hare Krșna movement), unpublished M. A. thesis, Praha: Hussite Theological Faculty, Charles University 2013, $72 \mathrm{p}$.

6 Jitka Schlichtsová, "Pán Kršna a oddané děti” [“Lord Kṛṣna and the devotee children”], Dingir (3/2013): p. 74-76. 
to the Gurukulas. ${ }^{7}$ Nevertheless, Fárek touches the phenomenon only briefly, in the context of status of families and family lives in ISKCON and puts the stress on the abuse of children in the Gurukulas.

If we are to understand the phenomenon of education in the Hare Krṣna movement, we need to look at the literature Hare Kṛṇa devotees publish and distribute themselves. These are mostly the books written by the movement's founder Bhaktivedanta Swami Prabhupāda and to lesser extent also by others. The most frequently quoted books include Bhagavad-gitä As It Is (1991) and The Nectar of Devotion (1992). ${ }^{8}$ However, the personal views of the movement's founder regarding education and its logic and goals can be found in many other sources. ${ }^{9}$ The 1984 brochure Srila Prabhupada on Gurukul, which is a compilation of Prabhupāda's letters and interviews, contains the movement's founder's instructions on how a Gurukula works and it can therefore provide a more general outlook on Prabhupāda's view on education and the ideal upbringing. Unfortunately, the full version of the book is practically impossible to find..$^{10} \mathrm{~A}$ Gurukula ex-teacher Bhurijan Dasa is an author of The Art of Teaching, another work that systematically summarizes instructions for the education of children in the Hare Kṛṣna movement.11 I also used many articles published in the movement's periodicals ISKCON Communications Journal and Náma Hatta. ${ }^{12}$

There is only one scholarly analysis of the failed attempt to found a Czech Gurukula in 1995-1997 - that is Martin Fárek’s short article from 2001 "Gurukula jako zkouš-

${ }^{7}$ MARTIN FÁREK, Hnutí Haré Kršna: Institucionalizace alternativního náboženství [The Hare Krșna Movement: On the institutionalization of alternative religions], Praha: Karolinum 2008, 208 p.

8 A. C. Bhaktivedanta Prabhupada, Bhagavad-Gìtā As It Is, $2^{\text {nd }}$ ed., Los Angeles et al: The Bhaktivedanta Book Trust 1989, 924 p.; A. C. Bhaktivedanta Prabhupada, The Nectar of Devotion: The complete Science of Bhakti Yoga: A Summary Study of Śrīla Rüpa Gosvāmī’s Bhakti-rasāmrta-sindhu (online), The Bhaktivedanta Book Trust 1969, 502 p., available online at https://ebooks .iskcondesiretree.com/pdf/Nectar_of_Devotion_with_Sanskrit/Nectar_of_Devotion_with Sanskrit.pdf.

9 A. C. Bhaktivedanta Prabhupada, Beyond Birth and Death (online), The Bhaktivedanta Book Trust 1972, 68 p., available online at http://prabhupadabooks.com/pdf/Beyond_Birth_and _Death-Original_1974_edition_scan.pdf; A. C. Bhaktivedanta Prabhupada, "Śrīmad Bhāgavatam canto 1-10" (online), The Bhaktivedanta Book Trust 1972, available online at https://krishna .org/srimad-bhagavatam-original-edition-pdf-download/; A. C. Bhaktivedanta Prabhupada, Life Comes from Life (online), Bhaktivedanta Book Trust 1973, 137 p., available online at http:// www.krishnapath.org/free-ebooks-audiobooks-of-srila-prabhupada/life-comes-from-life/; A. C. Bhaktivedanta Prabhupada, The Science of Self-Realization (online), The Bhaktivedanta Book Trust 2008, 233 p., available online at http://www.krishnapath.org/free-ebooks-audiobooks-of-srila-prabhupada/the-science-of-self-realization/.

${ }^{10}$ A selection of Prabhupada's instructions on Gurukul is avaiblable online: "Prabhupada on Gurukul" (online), March 2018, available online at https://krishna.org/srila-prabhupada-on-gurukul/.

${ }^{11}$ Bhurijana Dasa, The Art of Teaching: A Guide for Training Our Children in Krṣna Consciousness, Vrindavana Institute for Higher Education 1995, $506 \mathrm{p}$.

${ }^{12}$ Náma Hatta is a magazine published by the ISKCON in Czech Republic. The following articles focus specifically on education: AsvaHARI DÁsa, "Gurukula v Mayapuru” ["Gurukula in Mayapur"], Náma Hatta (1/ 1997): p. 6-9; JóGA MáJá DÉví DÁsí, "Škola základ života” [School, the Basis of Life"], Náma Hatta (4/2008), p. 12-13; JALANGi DÉví DÁsí, "Děti jsou velice citlivé” ["Children are very sensitive"], Náma Hatta (4/2008), p. 14-15; "Gurukula 1/4", Náma Hatta (2/2009), p. 25; “Gurukula 2/4”, Náma Hatta (3/2009), p. 22; “Gurukula 3/4”, Náma Hatta (4/2009), p. 30-31; and “Gurukula 4/4”, Náma Hatta (5/2009), p. 23. 
ka: Ohlédnutí za úsilím založit školu hnutí Haré Kršna” ("Gurukula as a Challenge: Looking Back at an Intent to Found a Hare Kṛ̣ṇa School”). ${ }^{13}$ Between 1993 and 1998, Martin Fárek was a member of the Hare Kṛnna movement himself and he was one of the authors of the project of establishing a Gurukula in Hare Kṛṣna environmentally conscious farm in Kršnův dvůr near Městečko u Benešova in Central Bohemia. Fárek was in charge of communication with the authorities during the process of including Gurukula Kršnův dvůr into the network of schools and educational institutions presided by the Czech Ministry of Education, Youth and Sports (MŠMT). In this article's conclusion, I offer a short overview of the process. ${ }^{14}$

\section{The Principles of Hare Krṣna education}

\section{The basic points}

Since the Hare Kṛṣna movement emerged from the Gaudiya Vaishnava tradition, it also follows its predecessor's educational model: from early childhood, the children are entrusted to the care of a spiritual teacher, a Guru. The Guru and his disciples together form a single community - a Gurukula (based on Sanskrit guru, "teacher" or a "master", and kula, "extended family"). The importance, position and personal characteristics of the Guru are described in the Indian book of Guru Gita, one of the traditional Hindu scriptures. The term "Guru" is believed to have been created from the syllables $g u$ ("darkness") and $r u$ ("light"). In this sense, a Guru is supposed to bring people from darkness into the light. A Guru can also be titled as "enlightened master", "perfect teacher" or "living god". ${ }^{15}$

In the original sense, the Guru and the disciple (brahmacārì) enjoy a very close relationship. Even though it seems the pupil's duty is to serve the Guru in accordance to his or her age or abilities, the servitude's reason is the closeness to the Guru it creates. The pupils are allowed to remain in the Guru's presence and absorb his knowledge, ask, discuss and learn. In other words, the relationship leads to the most basic type of human education - learning by imitation. "Its core goal should be study of the scriptures, development of self-control and other personal qualities and acquiring abilities useful in life."16 The basis of the Guru-disciple relationship is trust and love. The disciples are supposed to love the master - not because it's their duty, but because they genuinely like to serve him, since the Guru treats them with kindness, takes care of them and gently and patiently teaches them his wisdom. This is how Prabhupāda explained the relationship between the Guru and his disciples to his first devotees:

${ }^{13}$ Martin FÁREK, “Gurukula jako zkouška: Ohlédnutí za úsilím založit školu hnutí Haré Kršna”["Gurukula as a Challenge: Looking Back at an Intent to Found a Hare Kṛṣna School”], Dingir (2/2001): p. 20-21.

${ }^{14}$ A detailed analysis of the case based on my interviews with Martin Fárek was presented in my M.A. thesis: Schlichtsová, Výchova a vzdělánív hnutí Hare Kršna, p. 47-112.

${ }^{15}$ FÁREK, "Gurukula jako zkouška", p. 20-21.

${ }^{16}$ FÁREK, Hnutí Haré Kršna, p. 125. 
Initiation means that the spiritual master accepts the student and agrees to take charge, and the student accepts the spiritual master and agrees to worship him as God. ${ }^{17}$

In other words, the Guru's role is not unlike that of the child's parents. Štampach adds: "The obedience to the Guru only makes sense if it's voluntary and based on personal choice and selection. In the true Guru-disciple relationship, obedience is born from trust and love."18

Whole concept of child education is deduced from the idea of four stages (ạsrama) of life - brahmacārī, gṛhastha, vānaprasha and sanjāsī. The brahmacārī's role consists in studying of the Vedas and listening to the spiritual master. Some children, especially little Brahmin boys, left their families and joined their spiritual master's family as early as 5 years of age. Around the age of 14, some of them went on to continue their studies in one of the big Brahmin centers. During the years of their study, they were expected to remain celibate and live an ascetic life, focusing only on the study of the scriptures, service to their Guru and maintaining a daily regime. As Prabhupāda says, "Study of the Vedas is not meant for the recreation of armchair speculators, but for the formation of character." 19 The most important positive characteristics are humility and devotion and this type of education is specifically aimed to create them in the disciple. In Nīti Śāstra, ${ }^{20}$ Paṇdita Cānakya states: “Those who are uneducated do not shine even if they are endowed with beauty and youth and are born in renowned families just like kimsuka flowers which are beautiful but odourless." ${ }^{21}$ Prabhupāda briefly comments to this quote: "Education is required to help culture. Not that you take degrees from the university and remain a dog. That is not education." 22

\section{Prabhupāda's view}

Prabhupāda often referred to American public schools as "slaughterhouse". He specifically criticized the memorizing of a plethora of encyclopedic knowledge and the simultaneous absence of spiritual education, which, in his opinion, would better help with character development. He insisted that only after the pupil had studied the Vedas under his master from 5 to 20 years of age, he may become a person of perfect

17 Satsvarupa Dasa Goswami, Prabhupada: Your Ever Well-Wisher, Los Angeles et al: The Bhaktivedanta Book Trust 1995, p. 54.

18 Ivan O. ŠTAMPACH, "Problémy náboženské autority: Nalézt rovnováhu ve vztahu k autoritě” ["Problems with Religious Authority: Finding a Relationship with an Authority"], Dingir (1/1999), S. $14-15$.

19 PrabhupāDA, Bhagavad-Gìtā As It Is, p. 392.

${ }^{20}$ Paṇdita Cāṇakya, also known as Kauṭilya or Viśnugupta lived in 4th century. The title of his work, Nìti Śāstra, is usually translated as "civil and moral law".

${ }^{21}$ Paṇdita Cāṇakya, "Niti-Saara - Collection of Subhashitas - Sanskrit English” (online), accessed March2017,p.12, availableonlineathttps://ia802606.us.archive.org/26/items/Niti-sara-Collection OfSubhashitas-SanskritEnglish/Niti-sara-CollectionOfSubhashitas.pdf.

22 [AninterviewwithPrabhupada](online), Mumbai, 19thDecember 1975, accessedMarch2018, available online at https://prabhupadabooks.com/conversations/1975/dec/morning_walk/bombay /december/19/1975. 
character. ${ }^{23}$ The founder of ISKCON put great stress on the study of traditional scriptures. He insisted throughout many of his works, translations, commentaries, and interviews that reading the Vedas is the best was to learn devoted service. For instance, in The Nectar of Devotion he paraphrases the Brahma-yāmala:

If someone wants to pose himself as a great devotee without following the authorities of the revealed scriptures, then his activities will never help him to make progress in devotional service. Instead, he will simply create disturbances for the sincere students of devotional service. ${ }^{24}$

According to Prabhupāda, study of the scriptures has the greatest impact on spiritual growth. He considered the traditional texts to be the flawless and full revelation of the entire truth. Specifically, he insisted that in order to advance in devotional service, one especially needs to study Bhagavad-Gītā and his own (Prabhupāda’s) commentaries and translations:

Practically, if one very carefully reads Bhagavad-gītā, Śrīmad-Bhāgavatam, Teachings of Lord Caitanya and this Nectar of Devotion, that will give him sufficient knowledge to understand the science of Kṛṣna consciousness. One need not take the trouble of reading other books. ${ }^{25}$

\section{Náma Hatta - Gurukula}

In order to clarify which methods, tools and principles the Hare Kṛṣna movement uses in its education, we can use a four-volume article published in 2009 in the Czech Hare Kṛșna magazine Náma Hatta. ${ }^{26}$ The article is dedicated to the most important features of both children and adult education, which serve to prepare the movement's members for further public work and spreading the devotees' teachings. The series uses the following motto: "Books are the basis, preaching is the essence, utility is the principle and purity is the force." One by one, the article presents all the principles and emphases of the ISKCON education. In the end, all lead to the same goal: to form future missionaries and preachers of devotion to Kṛṣna.

\section{First part: the books are the basis}

The first article lays down the three core principles:

a) All the basic concepts of education ought to be based on Srila Prabhupāda's books.

${ }^{23}$ PrabhupāDa, Bhagavad-Gìtā As It Is, p. 392.

${ }^{24}$ Prabhupada, "The Nectar of Devotion", p. 64.

${ }^{25}$ Prabhupada, "The Nectar of Devotion”, p. 68. In this chapter Prabhupāda refers to reading a spiritual master's text; however, the same applies to the disciples.

${ }^{26}$ The magazine is published by Centrum pro védská studia (Center for Vedic Studies) in Lužice u Prahy. 
b) The state of mind, in which the education is held, ought to be based on Srila Prabhupāda's teachings.

c) The school's results should be evaluated through Kṛṣna conscious standards set by those books. ${ }^{27}$

The article then proceeds to elaborate upon these principles, insisting that all the information that a Kṛṣna devotee needs to perfect his life, can be found in Prabhupāda's writings. Even if the information is not explicitly formulated, the books always contain at least indirect references and instructions. The article states that if a person studies those themes diligently and seeks those topics, he or she will find a great deal. Based on this type of reasoning, the article declares:

If a person explores those books, sincerely looking for guidance in the questions of education, he will find it. If we meticulously analyze all the examples of instructions given to students, sons or pupils in Śrīmad Bhāgavatam, we would be able to learn a lot about educational techniques and the basics of learning..$^{28}$

In other words, the core principle of the contemporary Hare Kṛṣna movement and its Gurukula education is the idea that the only knowledge that the pupils needs is already contained in Prabhupāda's books. Those that seek knowledge or ways to educate themselves should only look for inspiration there, examining their assumptions in the light of the ISKCON teachings. When making conclusions, they should only take Prabhupāda's teachings into account, which, so to say, play the role of a filter of possible interpretations for both the content and the form of education.

\section{Second part: preaching is the essence}

The objective of the second part of the article is to discuss the ultimate goal of Hare Kṛṇa education and the ways the Gurukula helps to achieve it:

a) The students will be trained (both by study and practice) in the philosophy and devoted principles of the ISKCON.

b) During the training, the students will have to listen to preaching as much as it is practical, so that the preaching enhances a proper spiritual development.

c) The teachers themselves must be preachers that actively use their talent to spread their mission.

d) The apex of the Gurukula system should be the formation of preachers of Kṛṣna consciousness that would unwaveringly focus on ISKCON principles established by Śrīla Prabhupāda. ${ }^{29}$

27 "Gurukula 1/4", p. 25.

28 "Gurukula 1/4", p. 25.

29 “Gurukula 2/4”, p. 22. 
These principles clearly declare the abovementioned goals of ISKCON's Gurukula education: a professional preparation of new preachers of Kṛṣna consciousness, whose main objective is to fulfill the movement's mission established by ISKCON's foundation chart. At the same time, all the seven articles of the chart explicitly state that the movement's essence is its missionary work. The article then elaborates upon these principles and points out those controversial elements in master-pupil relationship that are often termed as "Guruism": ${ }^{30}$ the creation of pupil's dependence on the master and his or her compliance and devotion both to him and his objectives. In respect to this, Náma Hatta gives the following commentary:

If the student goes out to preach with his master, he can develop the ability to control his senses and foster respect and devotion for his master much earlier. This also enables him to develop the sudridha-sauhridāh - a lasting friendship with the teacher.

When the new student goes out to preach for the first time, he will feel insecure and frightened. Nevertheless if he observes his master replying to questions he would not be able to answer himself or doing things he would not be able to do yet, the pupil will develop a respect and dependence on the master, realizing he needs him.

If the student lives at home, he remains dependent on his parents and feels no need to rely on the master; the true friendship then develops much slower. Greater engagement with preaching together with listening to it will bring the masters and pupils close together. The stronger their relationship is, the easier it is to direct the students and the lower their tendency to have disciplinary problems gets.

Preaching together is also a way to share exciting experiences that will add a greater importance to their relationship. While preaching and travelling, each and every student must accept their share of responsibility, which will somehow ease the master's burden. And if the student helps with work the master would otherwise have to do himself, the master's interest in the student and his progress increases even more. The pupil then feels "needed" or "wanted", realizing he is able to live in an aśrama and to have a place at his master's side, and he well become happy in his seclusion from home. As the respect and friendship deepens, the student becomes more docile and happily acts in his master's favor. The preaching also gives the student a necessary practical use of the philosophy he has learned. ${ }^{31}$

Even at the first glance, this part of ISKCON's educational principles seems very controversial, since it contains an image of a master-pupil relationship that is openly manipulative and created to specific purposes. The dependence of the pupils on their

30 "Guruism" is usually understood as a system in which the master is endowed with a strong and unquestionable authority. At the same time, he requires an absolute devotion and blind obedience from the students, which in turn are used (or abused) to fulfill the master's goals. ŠTAMPACH, "Problémy náboženské autority", p. 14-15.

31 “Gurukula 2/4", p. 31. 
master is deemed desirable and the movement uses it for the formation of future preachers. To reach this goal, the masters should use the following: time spent together, shared experiences, taking the pupils out of their environment and inducing them to leave the comfort zone in their family, entrusting them with responsibilities and giving them a sense of their own importance and an indispensable role in their mission. The article presents those points in a clearly formulated and well thoughtout way, using them to secure the pupil's interest and obedience. At the same time, the text deals with the role of the master. He should take interest in his pupils since they alleviate him of some of his duties.

\section{Third part: utility is the principle}

The third part of the article series explains the relationship of education and the meaning of an individual's life. It returns to the nonsensical character of Western education and science, which is understood as atheistic and only of a speculative nature, containing partial, misleading, erroneous, and ever changing information:

The contemporary scholastics have no clear line of development and change all the time..$^{32}$

(...) In fact, contemporary knowledge is simply a study of the physical nature offered by social sciences and numbers. Moreover, it is not based on any authority - only on observation and logical conclusions. ${ }^{33}$

The article emphasizes the contrast between the Western type of education and the meaning of the Gurukula education. While the second article of the series identifies the goal of education as the practical formation of a future missionary, the third part puts the stress on the training of the pupils to escape the cycle of births and rebirths. It says:

The Gurukula should transmit the knowledge that helps the students to leave this material world and the Samssāra or the constant rebirth (gurōr na sa sjāt). We shouldn't care to transmit that type of "knowledge" that allows the students to specialize on an easy life and become successful or socially acceptable in this material world. Instead, we want to prepare them for leaving the world, not for living comfortably in it. ${ }^{34}$

In other words, "utility" means that the only meaning of human life is to seek spiritual wisdom which allows us to leave both the material world and the cycle of Samsāra. This is what education should supply. Only those abilities and information that lead to this goal are worthy of being transmitted and considered "practical" every other kind of knowledge is useless, as it leads people astray and lengthens their journey to salvation. Only stable and anchored knowledge, which is not subject to change or to new discoveries, is accepted by the Gurukula as "complete". This knowl-

32 "Gurukula 3/4", p. 30.

33 "Gurukula 3/4", p. 31.

34 "Gurukula 3/4", p. 31. 
edge, based on the Vedic literature and accepted as an ultimate authority, cannot be doubted, since it comes from God himself and was passed down by a succession of spiritual masters. This idea, combined with the principles of the previous part of the article, leads to the conclusion that the goal of education is to find a way to escape the Samsāra; the strategy to achieve this goal is devoted service, its clearest and most desirable form being missionary activity.

Even though the article does not fully reject modern sciences, it insists their acceptance depends on their usefulness:

Modern knowledge created many useful things that the movement for Kṛṣna consciousness can use, but we should never let them bewitch us and consider them life-giving or eternal. ${ }^{35}$

This means that the way we understand and use scientific knowledge must be subject to the movement's authoritative texts, which means to Prabhupāda's writings and the Vedic scriptures. Those are thought to be the sources of eternal and unchanging truth, which, in the moment of applying scientific knowledge, should be used as a filter. The article explicitly says:

By higher knowledge we mean Śrīla Prabhupāda's books; arts and social sciences are always subordinate to the eternal knowledge. ${ }^{36}$

In conclusion, the third part of the article returns to the Vedas once more, stressing again that they are the sources of all important knowledge. It also warns against studying books containing modern methods of education and against listening to the techniques of the karmi (those burdened by karma, those who don't live in the devoted service to Kṛṣna) - the devotees can contact the karmi only with the purpose of spreading Kṛṣna consciousness. ${ }^{37}$ If a method is working, then its principle must be contained in the Vedas. And if the devotees don't find it there, it means that the method should be avoided.

\section{Fourth part: purity is the force}

The final part of the series ${ }^{38}$ compares different types of human behavior. It divides these motifs in two groups: material and spiritual. As for material behavior, the article mentions two kinds of human relationships to the world at large - on the one hand, the humankind has a natural tendency towards enjoying nature and conquering it. On the other hand, the danger of anger and frustration leads men to an unnatural tendency to avoid the world; ultimately, this approach destroys the motivation for

35 “Gurukula 3/4", p. 31.

36 "Gurukula 3/4", p. 31.

37 "If you listen to non-devotees, you are in danger of contamination. If you try something you read and it works, you can start to trust them and meet with them more often." "Gurukula 3/4", p. 31.

38 "Gurukula 4/4", p. 23. 
spiritual activities. For example, children motivated by praise and reward won't be interested in the spiritual life, since they will be too comfortably settled in the superficialities of the material world. In this case, the article seems to refer to the fulfillment of one of the basic human needs of the Maslow pyramid - the need for recognition and respect. Nevertheless, the article does not say whether the teacher should incite the children's interest in a spiritual life by intentionally frustrating those needs.

The spiritual consciousness means that the person voluntarily acts only to please Kṛṣna and his or her Guru. Thus if a person understands the relationship of every act to Kṛṣna consciousness, he or she is inspired to act rightly. The Vedic education aims to destroy material motivation with three of its aspects: purity, authority acceptance and humble service.

Since purity refers to leaving material desires aside, it can be interpreted as frustration, even though it does not mean either hunger, rejection of the individual or no such thing. The concept refers rather to conquering these needs, a kind of detachment. The article explicitly mentions sexuality, since ISKCON considers it to be a key problem. Celibacy means conquering the strongest impulses and therefore if the individual achieves it, he or she will be rewarded by a higher level of spiritual knowledge and the power to bring others to Kṛṣna consciousness.

Controlling of one's needs also means humility and humble service. They are necessary to purify the children, make them accept learning as their duty and to incite humility and respect both towards their master and the scriptures in them.

\section{ISKCON Gurukulas around the world}

Now that we have described the theoretical bases of a Gurukula's functioning, we can have a closer look on the way ISKCON implemented this Gurukula type of education in the past. The practice has been problematic since the beginning and it has stained the movement's reputation in such a way that it has never fully recovered. The biggest problem was the abuse of children in the Gurukulas, both psychological and physical, which took place there almost from the start of the project in the 1970's and which has not been discovered until the 1990's. After making a brief summary of the scandal, I will add the main methods of how the movement tried to solve the situation. Finally, we will have a closer look at the form and organization of present Gurukulas.

\section{Child abuse in the ISKCON Gurukulas in the 1970-1980's}

According to Rochford, ${ }^{39}$ Prabhupāda started to ponder about the necessity of devotee children's education as early as 1968. As we saw in the last chapter, the main goal of the Gurukula would be to train its student in spiritual life, so that they learn devotion and escape the cycle of rebirth. Even though the Gurukula also taught academic subjects, its core objective was to teach the children control over their senses

${ }^{39}$ RochFord, "Education and Collective Identity", p. 30. 
and ascetic techniques. By means of obedience and self-control, the young devotee would reach self-realization in Kṛnna consciousness. Prabhupāda believed that due to the natural strength of the bond between children and their parents, there is little hope to teach the child self-control in the family environment. Children thus had to leave their families as early as at 4 or 5 years of age. Rochford quotes a 1990 interview with a parent, who at the same time was an ex-teacher in a Gurukula:

It's understood that the parent is lenient and easily influenced by the child because of the ropes of affection. So this is why it is best if a gurukula teacher is instructing them. ${ }^{40}$

The children remained in the Gurukula all year and parents were only allowed to visit during sporadic holidays. The pupils lived in āśramas ${ }^{41}$ together with their teacher who supervised them and took care of them. At first, the āśramas had the ratio of six to eight children of the same sex and age for one teacher. However, the number slowly grew, until one teacher was responsible for up to 20 kids. The Gurukula also had "academic" teachers who, as opposed to the āśrama teachers, were only responsible for teaching their subjects. ${ }^{42}$

The first Hare Kṛṣna áśrama school, which for a long time remained the only one, was founded in 1971 in Dallas, Texas. Since the authorities threatened to close it, two more were established in the USA - one in New Vrindaban, Virginia (a big ISKCON center) and one in Los Angeles. Short after, the Dallas Gurukula was indeed closed down - at this time it had about one hundred pupils between 4 and 8 years. By 1978, 11 āśrama schools had opened in the USA, but none of them survived longer than until 1986 - all were either closed or transformed into day schools. The only äśrama school left in the USA was Vaisnava Academy for Girls in Florida, which functioned both as a day school and a boarding school. ${ }^{43}$ At the end of the 1970's and the beginning of the 1980's, Gurukulas begun to emerge in other countries, such as Great Britain, France, Sweden, Australia and South Africa, ${ }^{44}$ but none of them remained an āśrama type of school. All contemporary Gurukulas outside of India are only day schools. In India, two boarding Gurukulas have appeared, one in Vrindavan and the other in Mayapur. Both of them still exist.

Since their beginning, the ISKCON Gurukulas wrestled with many problems. The reason was largely the fact that their education concept changed from following the

${ }^{40}$ RochFoRD, "Family Formation, Culture and Change in the Hare Krshna Movement", p. 67.

${ }^{41}$ Generally, the term āśrama is used for Hindu pilgrimage places, temples, and temple complexes. In the Hare Kṛ̣na movement, the term is used for separate community lodging spaces - usually one room is reserved for men (men's áśrama), the other for women and children (women's āśrama). In the Gurukula, it is a room used for the accommodation of a teacher and several children of the same sex and more or less the same age.

42 FÁrex, Hnutí Haré Kršna, p. 114.

${ }^{43}$ The part for boys was converted to day school after the teacher and director of the Gurukula was charged with abuse of four of his pupils of about ten years of age. He pleaded guilty and left ISKCON (FÁREK, Hnutí Haré Kršna, p. 114). As for today, not even the girls’ part offers the āśrama form of schooling.

${ }^{44}$ RochForD, "Family Formation, Culture and Change in the Hare Krshna Movement", p. 68. 
original Vaishnava principles towards fulfilling the necessities and goals of the Hare Kṛ̣na movement. In other words, the original idea of upholding the Indian education and its traditional value of a kind relationship between the master and his pupils gave way to alleviating the parent's responsibility for their children, so that they could return back to their missionary activities (and other work for the movement) as fast as they could. All family life was thus put under control and the devotees were free to spend all their energy on ISKCON missionary work:

Of course one of the main things that Prabhupada wanted to achieve was to free the parents from the encumbrance of the children. Because without children, and that responsibility, parents would be able to do more book selling and more preaching, and to devote full-time to institutional engagements. ${ }^{45}$

Rochford's research shows that three factors contributed to the creation of an environment that led to child abuse:

- » The emphasis on book selling, which spread the movement's mission and raised money for the movement;

- » insufficient support and control of the schools;

- » and the fact that parents were not informed of the true state of things in the Gurukulas.

These three factors cannot be separated - they blend into and influence one another. The parents couldn't possibly face and avoid the socially pathological phenomena that started appearing in the Gurukulas and slowly became the standard. It seems that the parents generally lived in communities far from the Gurukulas where their child lived and they got only fragmentary or possibly even intentionally distorted information. They were not allowed to visit the child often or engage personally in the Gurukula matters.

Other problematic aspect was the choice of teachers. As I mentioned, ISKCON put greatest possible emphasis on book selling and missionary work. Those two activities were seen as the best way to please both Prabhupāda and Kṛ̣ṇa. Unsuccessful sellers and missionaries were relocated to do other work - for instance, to teach in the Gurukulas. Unfortunately, since the most praised form of service lay in raising money to build new temples and centers, becoming a teacher was seen as being demoted to an inferior position. Subsequently, the frustrated teachers vented their dissatisfaction and anger on the children. Moreover, the ISKCON leaders did not want the Gurukulas to spend the hard-earned money - even Prabhupāda himself prioritized temple construction and refused to use the movement's financial means on the Gurukulas. Instead, he recommended to move the Dallas Gurukula to India. ${ }^{46}$ Nobody was really

${ }^{45}$ RochFORD, "Family Formation, Culture and Change in the Hare Krshna Movement", p. 68.

46 "Letter for Ramesvara no. 76-1-64 (23. 1. 1976)", in "Letters from Śrīla Prabhupāda Vol. V, 1975-1977” (online), The Vaishnava Institute, Culver City, 1987, p. 3055-3056, available online at http://www.krishnapath.org/free-ebooks-audiobooks-of-srila-prabhupada/prabhupada-letters/. 
interested in how the Gurukulas worked. Bharata Shrestha dasa, one of the ISKCON Communications Journal correspondents, wrote the following:

Children suffered denial of medical care for life-threatening illnesses, serious bruises and contusions, lost teeth, broken noses, scarring from caning, repeated sexual abuse and even homosexual rape at knifepoint. The perpetrators of these very serious crimes were none other than the teachers, the ashram leaders, the administrators, and in some cases even sannyasis and ISKCON gurus... An entire generation of children had been subjected to horrendous treatment at the hands of those entrusted with their welfare by parents who thought that they were doing what was best for their children. ${ }^{47}$

Rochford's research documents a plethora of mostly anonymous testimonies of the situation in the ISKCON Gurukulas in the 1970's and 1980's. I selected three of those testimonies that illustrate the situation well:

Seattle was hell because I was only six years old, my mom lived in Hawaii, and I have always been a very shy mommy's girl. The movement was in its earlier stages, and the devotees were fanatical - beyond fanatical. I mean, they would give us a bowl of hot milk at night, so I would, of course, pee in my bed. Then as punishment they would spank me very hard and make me wear the contaminated panties on my head. In general, at that time, because I was so young, I was so spaced out and confused. I would cry ... for my mom, but that wasn't allowed, so I would say I was crying in devotional ecstasy. I really regret Seattle because I had a dire need for my mother's warmth and reassurance at that time in my life.

I remember dark closets filled with flying dates (large 3-inch, flying cockroaches) and such, while beatings and "no prasādam" [spiritually blessed food] for dinner became everyday affairs.

The teacher used to say, "Oh, you don't know when you are going to die. You could die in your sleep." And one day I was really bad and one of my teacher said, "Who knows you might die tonight. Krishna might be punishing you. He might be taking away your life."... And from that night on I used to pray every night, "Krishna, please don't kill me. I promise I will be a good girl tomorrow. Please let me get fixed up enough so I can go back to Godhead. Don't take me in my sleep." And for years I had insomnia. I was too afraid to go back to sleep. ${ }^{48}$

Another frequently discussed question was Prabhupāda's responsibility for the situation in the ISKCON Gurukulas - in some of his preserved letters, he explicitly approved of the äśrama Gurukulas with their difficult life conditions. Prabhupāda's words and their diverse interpretations by temple and âśrama authorities were in

\footnotetext{
47 Bharata Shrestha DASA, “ISKCON's Response to Child Abuse: 1990-1998” (online), ISKCON Communications Journal VI (1/1998), available online at http://content.iskcon.org/icj/6_1/6 1bharata.html.

${ }^{48}$ E. Burke RochFord, Hare Krishna transformed, p. 76.
} 
turn used as arguments against the parent's active involvement in the functioning of the Gurukulas and to silence their criticism of the conditions the Gurukula children lived in. For example, in one of the letters Prabhupāda writes the following:

That is a good proposal, that parents should not accompany their children. Actually that is the gurukula system. The children should take complete protection of the Spiritual Master, and serve him and learn from him nicely. Just see how nicely your brahmacharies are working. They will go out in early morning and beg all day on the order of the guru. At night they will come home with a little rice and sleep without cover on the floor. And they think this work is very pleasant. If they are not spoiled by an artificial standard of sense gratification at an early age, children will turn out very nicely as sober citizens, because they have learned the real meaning of life. If they are trained to accept that austerity is very enjoyable then they will not be spoiled. So you organise everything in such a way that we can deliver these souls back to Krishna - this is our real work. ${ }^{49}$

\section{And in another letter:}

Regarding Gurukula, it is not required that parents live there with there [sic] children. We can take care of the children, but not the parents. Any parents there must be engaged preaching and selling books, and going on the Samkirtan party. ${ }^{50}$

At the beginning of the 1970's, the number of the movement's members steeply grew and there was already an institutional structure standing between Prabhupāda and the common devotees; at that time consisting of Prabhupāda's more advanced pupils. His schedule was therefore too busy for him to observe the situation in the Gurukulas. Moreover, tendencies to avoid informing Prabhupāda of some matters slowly started to appear. Even though Prabhupāda was a man brought up in a different cultural tradition, for which the most important objectives of education are obedience and self-control, he nevertheless apparently condemned physical as well as psychological abuse of the pupils. The following Prabhupāda's letter dated to November 1972 proves this. It was addressed to a Gurukula ex-teacher by the name of Bhanutanya Dasi, who informed him about her experience with how the children are treated in the Gurukulas and about her decision to leave the movement permanently:

Now the thing is, children should not be beaten at all, that I have told. They should simply be shown the stick strongly. So if one cannot manage in that way then he is not fit as teacher. If a child is trained properly in Krishna Consciousness, he will never go away. That

49 “Letter for Satsvarūpa Dāsa no. 71-11-39 (25. 11. 1971)", in "Letters from Śrīla Prabhupāda Vol. III, 1970-1972" (online), The Vaishnava Institute, Culver City 1987, p. 1808, available online at http://www.krishnapath.org/free-ebooks-audiobooks-of-srila-prabhupada/prabhupada-letters/.

50 "Letter for Satsvarūpa Dāsa no. 73-4-20 (19. 4. 1973)", in "Letters from Śrīla Prabhupāda Vol. IV, 1972-1975" (online), The Vaishnava Institute, Culver City 1987, p. 2268-2269, available online at http://www.krishnapath.org/free-ebooks-audiobooks-of-srila-prabhupada/prabhupada-letters/. 
means he must have two things, love and education. So if there is beating of child, that will be difficult for him to accept in loving spirit, and when he is old enough he may want to go away - that is the danger. So why these things are going on - marching and chanting japa, insufficient milk, too strict enforcement of time schedules, hitting the small children? Why these things are being imposed? Why they are inventing these such new things like marching and japan like army? What can I do from such a distant place? They should run and play when they are small children, not forced to chant japa, that is not the way. ${ }^{51}$

Prabhupāda's insufficient effort to correct the child abuse in the ISKCON Gurukulas is often explained by the movement's growing organizational structure and institutionalization. Nevertheless, apparently even if the devotees informed him personally, he decided not to intervene - another case documented by Rochford attests this fact. A Gurukula ex-pupil explains how her father tried to draw Prabhupāda's attention to the situation in the school:

When I was 5 and $1 / 2$ years old, I'd been in gurukula [Dallas] since its [inception] (about 3 years). My dad had come to Dallas (against the wishes of his temple authority, who only cared about my dad's money-making ability on sankirtan) after discovering bruises all over my body on Rathayatra ${ }^{52}$ [festival] visit. After much discussion with the school authority, he found that he could not get them to change the policy of daily beatings. He removed me from the school. Very disillusioned, he nearly left ISKCON. On hearing that Prabhupada would be in L.A. [Los Angeles], we went there. When Prabhupada saw me he asked why I was not in the gurukula. My father told him that he'd removed me because of the daily beatings. Prabhupada told him that I belonged in gurukula and that if my dad had a problem with the treatment he should work to resolve it ... [Prabhupada] did nothing to resolve the situation. Instead of going himself or sending one of his top people to resolve the problems he sent my dad, who had never had any power. Needless to say, when my dad returned do Dallas nobody listened to him. If a problem arose at some temple or other, Prabhupada was more than willing to go or send someone effective to handle the situation, but for the kids he sent my dad, who was effective at getting people to give him money. ${ }^{53}$

Question remains: did those parents, who didn't want to get rid of their children or who knew about the situation in the Gurukulas, even have a choice? Were they granted the possibility to keep the children and educate them at home or use the Gurukula as a day school? Apparently, Prabhupāda's written instructions as documented in his letters differ from ISKCON's usual practices. However, it is also possible that Prabhu-

51 “Letter for Bhanutanya Dasi no. 72-11-21 (18. 11. 1972)", in "Letters from Śrīla Prabhupāda Vol. IV, 1972-1975” (online), The Vaishnava Institute, Culver City 1987, p. 2155, available online at http://www.krishnapath.org/free-ebooks-audiobooks-of-srila-prabhupada/prabhupada-letters/.

52 A big Hare Krșna festival consisting of a procession with a chariot, several meters high, carrying Prabhupāda (today it carries his statue).

${ }^{53}$ RochFoRD, Hare Krishna transformed, p. 87-88. 
pāda's standpoint changed as he received more and more parents' petitions and news about the situation in the Gurukulas. This is Prabhupāda's answer to Tirthanga dasa dated to $14^{\text {th }}$ of March, 1975:

Regarding sending children to Gurukula, that is also optional, not compulsory. The most important things are that you follow very carefully all of the rules and regulations such as rising early, and having mangala arati and classes, etc. and that you chant at least 16 rounds daily without fail. These things are most essential for your spiritual advancement and then everything will be alright. ${ }^{54}$

On the other hand, the actual practice of the movement strongly differed from this picture - again, we know this thanks to the devotees' experiences documented in Rochford's research. They confirm that the parents were under constant pressure to send their children to Gurukulas. A long-time teacher's memory follows:

I remember in New York the Temple President told one women, "You don't send your kid to the gurukula you don't live in temple." 55

\section{A Hare Kṛṣna mother recalls the following:}

We did try the asrama for a week but she was very upset and unhappy. So you see that and think, you want your child to be happy. And even though there were various devotees around us saying this and that. Because I am a social person I was worried about what everyone was thinking. And even my spiritual master was saying, giving hints, "Why isn't she here (in the gurukula)?” ... And believe me, it would've been easier just to send my child out to the gurukula. Much easier. But intuitively, I just thought it's not right. I just can't do that. ${ }^{56}$

Other parents that wanted to keep the children and only send them to the Gurukula during the day, met with this type of argument:

Prabhupada made this point strongly, even though we forget. Gurukula means residing. Jagadisha [ISKCON's Minister of Education] asked him: "What if a parent wants to keep a child outside and bring them just during the day?" Prabhupada said: "I've already told you. Gurukula means residing. We have room for children, not for parents. ${ }^{57}$

\footnotetext{
54 “Letter for Tirthanga dasa no. 75-3-18 (14. 3. 1975)", in "Letters from Śrīla Prabhupāda Vol. V, 1975-1977” (online), The Vaishnava Institute, Culver City, 1987, p. 2777, available online at http:// www.krishnapath.org/free-ebooks-audiobooks-of-srila-prabhupada/prabhupada-letters/.

${ }_{55}$ RochFord, "Family Formation, Culture and Change in the Hare Krshna Movement", p. 68.

${ }^{56}$ RochFoRD, "Family Formation, Culture and Change in the Hare Krshna Movement", p. 68.

${ }^{57}$ Rochford, "Family Formation, Culture and Change in the Hare Krshna Movement", p. 68.
} 
Nevertheless, the parents did not remain deaf to the Gurukula problems - instead of sending their children there, more and more of them preferred state schools. In 1992, approximately $75 \%$ of ISKCON children went to non-ISKCON primary schools and $95 \%$ of the teenagers attended state high schools. ${ }^{58}$ It was probably these numbers that forced the ISKCON leaders to focus on the Gurukula problem: this also led to re-opening old abuse cases.

\section{The 1990's: solving the abuse problem}

The first step towards a solution was the Resolution 90-119 accepted in 1990 at the Mayapur meeting of the GBC. ${ }^{59}$ This document suggested the communities should appoint 2-3 persons to investigate suspicions of child abuse and to report to the authorities. Subsequently, they had to inform local ISKCON leadership about those cases. Persons suspected of child abuse were immediately suspended from the projects they participated in; this was often solved by transferring the person to another community. Meanwhile, the "suspect" was assigned to another type of service; sometimes he or she was expelled from the movement. Those who were "proven" guilty of child abuse could never return to their community of origin, unless a written agreement was presented signed by more than $75 \%$ of the parents. ${ }^{60}$

Since the resolution had the form of a suggestion and established no penalties for those who wouldn't comply, it was not mandatory and it took some time until temple directors started acting in accordance with it. Then the schools and communities started establishing Child Protection Teams (CPT). The biggest problem of the resolution was that it did not take into account past cases that had already been discovered. It also omitted the question of care for the abused children, leaving it up to their parents and the temple authorities, as well as prevention against future child abuse. ${ }^{61}$

On the other hand, the Resolution had its positive effects - at least it opened the way to solving the child abuse problem. It is true that neither the 1990 international meeting of the GBC in Mayapur nor Resolution 90-119 admitted that the situation was deeply rooted in the way ISKCON worked and in its chief priorities. At this point, the movement didn't consider it necessary to fundamentally change the way ISKCON worked. Nevertheless, it was the first time the Hare Kṛ̣na realized that this state of affairs was not the result of individual teachers' personal failure - instead, it was a universal and widespread problem that troubled the whole movement. The ISKCON leaders gave a clear sign that a matter of such a general and complex nature could not be left to the local temple authorities to resolve and the movement's central

${ }^{58}$ Preventing Child Abuse in ISKCON: A Manual for ISKCON Schools and Communities, ISKCON Board of Education [undated], p. 42.

${ }^{59}$ Governing Body Commision, the movement's executive office founded in 1970.

${ }^{60}$ BHARATA ShrEstha DASA, “ISKCON's Response to Child Abuse: 1990-1998”, http://content .iskcon.org/icj/6_1/6_1bharata.html.

${ }^{61}$ Bharata Shrestha DASA, "ISKCON's Response to Child Abuse: 1990-1998", http://content .iskcon.org/icj/6_1/6_1bharata.html. 
management (GBC) were deal with it instead. Even though the 1990 meeting did not lead to an effective solution or to prevention of further abuse, at least it brought an impulse to start investigating and punishing the cases and took first steps towards it.

The second step was the meeting of the North-American GBC in May 1996. The management invited a group of adult Gurukula ex-pupils who experienced child abuse during their stay in the ISKCON schools. I quoted some of their testimonies in the last chapter. During the meeting the management already established a group by the name of Children of Krishna with the following objective:

To support, further, and protect the education, economic, emotional, and spiritual advancement of the children of the Hare Krishna Movement. ${ }^{62}$

The group was basically a fundraising team of first and second generation devotees that assisted young people with financing their higher education and arranged therapeutic help for those who experienced any kind of abuse. ${ }^{63}$

At more or less the same time, the movement launched the VOICE webpage. The site's purpose was to provide access both to the results of North-American GBC meetings and to information regarding the abuse cases, as well as their solutions and consequences. This led to a new breakthrough - those activities made it clear that the situation required a personal engagement of each and every ISKCON member:

In other words, the mood changed from "they [meaning ISKCON authorities] ought to do something" to "we [meaning local communities and parents] ought to do something". ${ }^{64}$

In 1998, another GBC meeting in Mayapur accepted Resolution 98-305, which established a child protection policy and standards that every person working with children should meet. At the same time, Resolution 98-305 made reopening and solving the old cases possible, establishing the rules of inner ISKCON court proceedings including penalties for proven crimes and misdemeanors. In April 1998, the movement founded the Central Child Protection Office, today known as the Association for the Protection of Vaisnava Children. ${ }^{65}$

Clearly, after some time the problem of child abuse was fully put into spotlight. Some articles published in ISKCON Communications Journal also attest this turn of the events. This refers to the writings of E. Burke Rochford, who was invited to help

62 Bharata Shrestha Dasa, “ISKCON’s Response to Child Abuse: 1990-1998”, http://content .iskcon.org/icj/6_1/6_1bharata.html.

${ }^{63}$ Bharata Shrestha DaSa, "ISKCON's Response to Child Abuse: 1990-1998”, http://content iskcon.org/icj/6_1/6_1bharata.html.

${ }^{64}$ Bharata Shrestha DASA, "ISKCON's Response to Child Abuse: 1990-1998”, http://content .iskcon.org/icj/6_1/6_1bharata.html.

${ }^{65}$ Martin FáreK, Hnutí Haré Kršna, s. 121. 
resolve the situation, as well as the testimonies of the victims themselves and general reflection of Gurukula-style education and its usefulness in adult life. ${ }^{66}$

Nevertheless, the preventive measurements are not always respected and followed. Even though the countries of Western Europe and North America keep an open approach and try to fight child abuse as much as they could, the rest of the world may not follow suit. Communities of these countries sometimes fail to establish the Groups for the Protection of Vaisnava Children and the ordinary members have no access to information about child abuse. This applies specifically to Eastern and Central Europe, Russia, and Latin America. Some of these communities lack their own websites and it is very hard to penetrate into their internal affairs. At the same time, in cases where the suspected party enjoyed high status in the movement, even the local leading ISKCON authorities may try to slow down or even sabotage the investigations. ${ }^{67}$ These facts naturally cast some doubt on the ISKCON leaders' sincere intentions to solve the problem of child abuse and to reform the Gurukulas.

\section{Gurukulas today}

According to available documents, there are currently 27 active Gurukulas. ${ }^{68}$ In most cases, these are day schools; the pupils keep living with their families. They often offer education for children from pre-school years up to the end of the compulsory education (this in most of the world's countries means up to 14 or 15 years of age). Some Gurukulas also offer high school studies and some even adult education. The day Gurukulas also have the same range of services as state schools - that is, school buses, meals, school hobby clubs, and other leisure activities. And even though they are intended for ISKCON members, they accept other children as well. As such, they offer an alternative to a standard type of education.

\section{Contemporary Gurukula schooling}

The Gurukulas' internet pages allow us to survey at least to some extent the organization and methods of the contemporary Gurukula education. I base my conclusions on the information available on the online websites of the following Gurukulas: Bhaktivedanta Manor Primary School, ${ }^{69}$ Bhaktivedanta Gurukula \& International School

${ }^{66}$ See p. e. Gabriel DeAdwyler, "Fifteen Years Later: A Critique of Gurukula", ISKCON Communications Journal (1/2001): p. 13-22. The author is a former Gurukula pupil and the article describes his school experiences and subsequent problems he had to wrestle with as an adult.

${ }^{67}$ Bhaktin Miriam, "The Persistent Child Abuse Problem in the Hare Krishna Movement" (online), Chakra Discussions, August 2004, accessed February 2016, available online at http:/ www .chakra.org/discussions/GurAug01_04.html.

${ }^{68}$ The actual list of the available Gurukulas can be found on ISKCON's website dedicated to education (See "Schools" (online), ISKCON Ministry of Education, accessed February 2016, available online at http://iskconeducation.org/category/schools/. Only some of those Gurukulas have their own websites - some only offer contact e-mail addresses.

${ }^{69}$ Bhaktivedanta manor: Home of the Hare Krishna (online), acccessed February 2016, available online at http://www.bhaktivedantamanor.co.uk/home/?tag=gurukula. 
Vrindavan, ${ }^{70}$ Sri Mayapur International School, ${ }^{71}$ Bhaktivedanta Academy Mayapur, ${ }^{72}$ Bhaktivedanta Swami Gurukula Australia, ${ }^{73}$ and Sri MayapNew School - Escola Bhakti ISKCON Franco da Rocha Brasil. ${ }^{74}$

The day programs largely differ, depending on whether the Gurukula belongs to a specific community (with only very few children from outside of it), or it is a Gurukula that serves for all the children from the surrounding neighborhoods or a boarding (āśrama) Gurukula. In any case, the basic organizational and didactic methods remain the same. The actual learning schedule is organized according to a typical ISKCON's daily program.

Both the children and the adults wake up around 4 A.M. and together with their parents attend the morning devotion. Around 5 A.M. they leave for the school club, where the engage in leisure activities supervised by a teacher. A typical example of these activities would be chanting, reading of Bhagavad-Gitā or other texts the community accepts, practicing theatrical performances intended for the parents, drawing, and narrating stories from the life of Kṛnna, Caitanya, or other important personalities. Then they have a breakfast (prasādam) together, which usually takes place between 7 and 8 A.M.

The actual learning begins at an hour which is considered typical by the local custom - in other words, it differs according to the country of the Gurukula. Since we can find most of the Gurukulas in English speaking countries, the learning system is based on the Anglo-Saxon model and the first lesson thus usually starts between 8 to 10 A.M. Younger children spend 3 to 4 hours a day learning, the older 4 to 6 hours. The core goal of the education is acquiring the knowledge both of Vedic literature and Prabhupāda's writings. However, the Gurukulas also have to offer the usual curriculum - this applies specifically to Western countries, in which the Gurukulas must fulfill the local requirements in order to be included into the system of state approved schools which are allowed to offer compulsory schooling. Some Gurukulas also organize international exams. For example, Sri Mayapur International School offers its students the possibility to study according to the curriculum of Cambridge International Examinations. ${ }^{75}$

At the moment, the available materials suggest that the abovementioned schools conceive their education in such a way as to transmit academic information adapt-

${ }^{70}$ The Bhaktivedanta Gurukula and International School (online), accessed January 2018, available online at http://www.bgis.org/.

${ }^{71}$ Sri Mayapur International School (online), accessed January 2018, available online at www .mayapurschool.com.

${ }^{72}$ Bhaktivedanta Academy (online), accessed January 2018, available online at http://bhaktivedanta academy.com/.

${ }^{73}$ New Govardhana Australia (online), accessed February 2016, available online at www.newgovardhana.net/gurukula. At this point, the website is out of order and apparently wasn't replaced by a different one.

74 "Fundacao Bhaktivedanta", (online), Facebook.com, last updated January 2012, accessed January 2018, available online at https://www.facebook.com/permalink.php?story_fbid=2846955582443 34\&id $=151919578188600$.

75 "Curriculum" (online), Sri Mayapur International School, accessed January 2018, available online at http://mayapurschool.com/curriculum/. 
ed to the age of the pupils, but at the same time to allow the children to use this knowledge in their practical life. The goal is not to make the children memorize encyclopedic knowledge and leave its application in daily situations up to them. On the contrary - the schools only teach those things that help the devotees in their practical life - meaning, as I have sufficiently demonstrated, a devoted service to Kṛṣna. The following comparison illustrates the situation.

In a standard school, the mathematics lessons are conceived in such a way that the pupil would proceed from concrete tasks (such as counting apples, pears etc.) to working with symbols (numbers) and formulae and then to applying these formulae to a concrete problem that can appear in practical life. This means that standard school education proceeds from the general (symbolic) as it appears in schoolwork to concrete problems as they appear in practical life. The Gurukula, on the other hand, does not teach the pupil to work with formulae and symbols - instead, it emphasizes solving practical-life situations right from the start. As such p. e. calculate the total price of a shopping list or the quantity of money the shopkeeper returns them after paying with a big note, create a home budget, compare the size of crops, etc. In other words, the school's objective is to teach children to solve basic situations of life. Making general or abstract conclusions is secondary and the school leaves it to the child. Thus, in effect, the schools proceed the other way: from the concrete to the general.

The Gurukulas' schedule is not always divided into different subjects arranged to blocks of time - specifically the little children learn in a different way. The education uses various methodical and didactic forms and emphasizes the connection of relationships, phenomena and situations that have something to do with the discussed problem. Instead of gaining empirical understanding of the problem by means of intellect and encyclopedic knowledge, the goal is to experience and perceive the lesson's content as a reality of life. We might say that it is a kind of project-based learning.

In practice, the teaching may look like this: instead of teaching math one hour, biology the next hour, literature the third and music the fourth, the teacher unites all of them into a single-themed project dedicated, for example, to cattle. The biology part is filled with information regarding anatomy, typical traits, food and the uses of the animals. To learn math, the children may calculate the costs of raising cattle, milk production, etc. Part of the program may be dedicated to reading literature, discussing assigned texts and chanting hymns, since in Hindu traditions, cow is considered sacred. This is how the learning program is built.

After the lessons, the Gurukula returns to the same type of program which took place in the morning. That is, mantra chanting, reading from the movement's scriptures, discussions, theatre, and lunch (prasādam). In case of the day Gurukulas, the pupils proceed to return back home to their parents to participate in individual activities according to the customs of their family and/or community.

In the äśrama Gurukulas, the program remains set until evening. The children study Bhagavad-Gītā and Prabhupāda's writings, meditate and fulfill their "housework" 
duties. This last point refers to the fact that the pupils are required to help with the Gurukula housework, which is distributed according to their age. During the work, they are under a constant supervision of one of the äśrama teachers. Websites usually agree on in the ratio of ten pupils on one teacher.

While the standard schools have two months of summer holidays and the schoolyear is divided in two semesters of five months each, the Gurukulas use trimesters of three months of learning followed by exams and a month-long holidays.

\section{Conclusion}

Although all the generations of Hare Kṛṣna devotees insist they derive their teachings from the tradition of Caitanya Vaishnavism, this tradition was gradually transformed by Western needs and lifestyle. The clash of cultures and slow building of the movement's organizational structure (which is not part of the tradition but reacts to modern needs) created different problems and conflicts. In his book, Martin Fárek analyzed this situation according to Thomas O'Connell's concept of soft, middle, and hard institution, examining their influences on the movement's development and the emergence of theological, social and political conflicts. ${ }^{76}$ I believe that the problems connected to the transfer of an Indian tradition to the West and the difference between the founder's thoughts and ideas on the one hand and their subsequent interpretation as offered by his pupils is the first reason why all three types of problems emerged. Most important of them are the social problems - that is, the low status of marriage and family, which is seen as something that only diverts the devotees' attention from service to Kṛ̣na. This creates a low status for women and children, opening the way to abuse.

The organization of learning in ISKCON Gurukulas has significantly diverged from its Indian model. Contrarily to it, the Gurukulas resembled big Anglo-Saxon boarding schools that housed hundreds of children (the äśrama gurukulas). Even though the founder's origins lay in the tradition of Caitanya Vaishnavism, he didn't manage to apply the traditional style of education in the Western environment and it's highly unlikely he even intended it. With all probability, his missionary orientation played a crucial role in all this, due to which everything in the movement and its devotees' life was considered inferior to the struggle to expand the movement as much as possible. The fact that the movement's chief objective was to spread Kụșna consciousness also meant that children and childcare occupied a marginal place. In fact, children were seen as a burden that hinders the parents' dedication to a devoted service. The most prestigious activities in the movement were public mantra chanting and book selling, since they brought money that could be used for temple construction and publishing more literature. Unsuccessful sellers were relocated to other forms of service, such as teaching in a Gurukula. In other words, the teachers had no previous training and

${ }^{76}$ FÁREK, Hnutí Hare Krṣna, passim. 
lacked a positive attitude towards children. They had no necessary personal traits, no experience, and their character wasn't formed by a long service to a spiritual master required by the tradition. In other words, they couldn't give the children what they lacked themselves. Moreover, they were often frustrated by the fact that their service was not bringing money to the movement and was thus considered inferior. Their low social status contributed to their attitude towards the children.

At the same time, the concept of education itself changed. At first, it was aimed to teach tradition, attitudes and habits that were supposed to lead to freedom from suffering by means of devoted service to Kṛṣna. Nevertheless, it quickly transformed into raising docile and effective missionaries who need to earn their salvation by absolute subordination to the ISKCON organization. During the first two decades of their existence, the Gurukulas used quite controversial methods to reach this goal. Unfortunately, the problem of both psychological and sexual abuse of children was ignored for a long time. The children were sent to distant Gurukulas far from their home, having little or no contact with their parents. If their families found out about the abuse, they could hardly accomplish any change without the leaders' support. Although Prabhupāda condemned some of the Gurukulas' practices during his life, he neither personally engaged in the problem nor tried to solve the situation actively. After his death, the situation in the Gurukulas kept getting worse. Testimonies gathered by $\mathrm{E}$. Burke Rochford attest to the way the Gurukulas worked; at the same time, technical problems and hygienic standards contributed to the life the children led there. The movement's leadership refused to pay for the reconstruction and preferred to close them or merge them together. Consequently, the children may have ended up living in a different country, sometimes even on a different continent than their parents.

The first intents to face the abuse cases date to the 1990's. Resolution 119 opened the way to monitoring the situation both in the Gurukulas and the communities and to prevent new cases of abuse; however, it did not address past cases or punish the culprits. It was just a kind of recommendation which was only actively pursued in North America and Western Europe. Step by step, other projects emerged which intended to spread information about the problem of child abuse in the ISKCON these were, among others, the VOICE website and Children of Kṛṣna group. Finally, the 1998 Resolution 305 cleared the way to prosecuting past offences.

Because of confirmed cases of abuse, all of the Western áśrama Gurukulas transformed into day schools. The only āśrama Gurukulas that remain today are in Vrindavan and Mayapur. In order to supervise the current Gurukula education, the movement established the Association for the Protection of Vaisnava Children. However, the available information applies mostly to North America, Australia, Northern and Western Europe and India. As for the countries of East Europe and South America, the situation is unknown and probably unchanged.

Between the years 1995 and 1997, the Czech ISKCON community of Kršnův Dvůr near Městečko u Benešova tried to establish its own Gurukula as well. In order to be able to offer compulsory schooling, Gurukula Kršnův Dvưr would have to be officially recognized by the Czech Ministry of Education, Youth and Sports and included in its 
list of schools and educational institutions. With the help of Agneta Kempe, a former Swedish Gurukula headmaster, the Czech devotees created a project and submitted an application which planned to open the school on the $1^{\text {st }}$ of September, 1995; however, the Ministry turned down the application. Even though leading Czech specialists in Pedagogy and Philosophy actively supported the project, the application was denied again in the following year. The reason for the Ministry's decision was that the expected number of the pupils was too small - while the law required a minimum number of 13 pupils to start a new school, only 4 children were expected to study in the Gurukula. Even though the law allowed for an exception to be awarded, the Ministry decided against it, which provoked public discussion of its possible undeclared motivation. The struggle for the Gurukula founding finally ended in 1997 when a huge breach of regulative principles was discovered, the guilty party being the leader of the farm. Consequently, the Kršnův Dvůr community practically dissolved. Since then, no further intents to found a Czech Gurukula have been made. Czech devotees either engage in homeschooling (available only for the first four grades of elementary school) or send their children to foreign Gurukulas.

As of yet, no Czech children's experiences with Gurukulas are available. A systematic and longitudinal research of the Czech Hare Kṛ̣na movement may also contribute to a better understanding of situation in other countries, especially in Great Britain and India, since these are the places to which Czech devotees most frequently send their children. The Gurukula websites give only little concrete information on their state of affairs and teaching methods. However, the available documents suggest that those Gurukulas included in the list on ISKCON's Ministry of Education's website focus mostly on teaching practical knowledge. Their character is probably only controversial in the context of Western tradition and its preference for Cartesian and encyclopedic knowledge. It will take a few years to see if the current system of Hare Kṛṣna education has changed enough to give the children a better perspective than it did in the past.

\section{References}

Asvahari DÁsA, “Gurukula v Mayapuru” ["Gurukula in Mayapur”], Náma Hatta (1/1997): p. 6-9.

Bhaktin Miriam, “The Persistent Child Abuse Problem in the Hare Krishna Movement" (online), Chakra Discussions, August 2004, accessed February 2016, available online at http://www.chakra.org/discussions/GurAug01_04.html.

Bhaktivedanta Academy (online), accessed January 2018, available online at http:// bhaktivedantaacademy.com/.

The Bhaktivedanta Gurukula and International School (online), accessed January 2018, available online at http://www.bgis.org/.

Bhaktivedanta manor: Home of the Hare Krishna (online), acccessed February 2016, available online at http://www.bhaktivedantamanor.co.uk/home/?tag=gurukula.

Bharata Shrestha DASA, “ISKCON’s Response to Child Abuse: 1990-1998” (online), ISKCON Communications Journal VI (1/1998), available online at http://content.iskcon .org/icj/6_1/6_lbharata.html.

Bhurijana Dasa, The Art of Teaching: A Guide for Training Our Children in Kṛ̦ṇa Consciousness, Vrindavana Institute for Higher Education 1995, 506 p. 
Bryant, Edwin F., and Maria Ekstrand, The Hare Krishna Movement: The Postcharismatic Fate of a Religious Transplant, New York: Columbia University Press, 2013, 496 p.

DeAdWyler, GABriel, "Fifteen Years Later: A Critique of Gurukula”, ISKCON Communications Journal (1/2001): p. 13-22.

FÁrek, Martin, “Gurukula jako zkouška: Ohlédnutí za úsilím založit školu hnutí Haré Kršna" "Gurukula as a Challenge: Looking Back at an Intent to Found a Hare Kṛșna School”], Dingir (2/2001): p. 20-21.

FÁREK, MARTIN, Hnutí Haré Kršna: Institucionalizace alternativního náboženství [The Hare Krșna Movement: On the institutionalization of alternative religions], Praha: Karolinum 2008, 208 p.

"Fundacao Bhaktivedanta", (online), Facebook.com, last updated January 2012, accessed January 2018, available online at https://www.facebook.com/permalink.php?story _fbid $=284695558244334 \& i d=151919578188600$.

“Gurukula 1/4”, Náma Hatta (2/2009), p. 25.

"Gurukula 2/4", Náma Hatta (3/2009), p. 22.

"Gurukula 3/4", Náma Hatta (4/2009), p. 30-31.

“Gurukula 4/4”, Náma Hatta (5/2009), p. 23.

[An interview with Prabhupada] (online), Mumbai, 19th December 1975, accessed March 2018, available online at https://prabhupadabooks.com/conversations/1975/dec /morning_walk/bombay/december/19/1975.

JALANGi DÉví DÁsí, “Děti jsou velice citlivé” [“Children are very sensitive”], Náma Hatta (4/2008), p. 14-15.

JóGa MÁJÁ DÉví DÁsí, “Škola základ života” [School, the Basis of Life”], Náma Hatta (4/2008), p. 12-13.

"Letter for Satsvarūpa Dāsa no. 71-11-39 (25. 11. 1971)", in "Letters from Śrīla Prabhupāda Vol. III, 1970-1972” (online), The Vaishnava Institute, Culver City 1987, p. 1808, available online at http://www.krishnapath.org/free-ebooks-audiobooks-of-srila -prabhupada/prabhupada-letters/.

“Letter for Bhanutanya Dasi no. 72-11-21 (18. 11. 1972)", in "Letters from Śrīla Prabhupāda Vol. IV, 1972-1975” (online), The Vaishnava Institute, Culver City 1987, p. 2155, available online at http://www.krishnapath.org/free-ebooks-audiobooks-of-srila-prabhupada /prabhupada-letters/.

“Letter for Satsvarūpa Dāsa no. 73-4-20 (19. 4. 1973)”, in "Letters from Śrīla Prabhupāda Vol. IV, 1972-1975” (online), The Vaishnava Institute, Culver City 1987, p. 2268-2269, available online at http://www.krishnapath.org/free-ebooks-audiobooks-of-srila -prabhupada/prabhupada-letters/.

"Letter for Tirthanga dasa no. 75-3-18 (14. 3. 1975)", in "Letters from Śrīla Prabhupāda Vol. V, 1975-1977” (online), The Vaishnava Institute, Culver City, 1987, p. 2777, available online at http://www.krishnapath.org/free-ebooks-audiobooks-of-srila-prabhupada /prabhupada-letters/.

“Letter for Ramesvara no. 76-1-64 (23. 1. 1976)”, in "Letters from Śrīla Prabhupāda Vol. V, 1975-1977” (online), The Vaishnava Institute, Culver City, 1987, p. 3055 - 3056, available online at http://www.krishnapath.org/free-ebooks-audiobooks-of-srila-prabhupada /prabhupada-letters/.

Paṇpita CĀṇakya, "Niti-Saara - Collection of Subhashitas - Sanskrit English" (online), accessed March 2017, p. 12, available online at https://ia802606.us.archive .org/26/items/Niti-sara-CollectionOfSubhashitas-SanskritEnglish/Niti-sara -CollectionOfSubhashitas.pdf. 
Prabhupada, A. C. Bhaktivedanta, Beyond Birt $h$ and Deat $h$ (online), The Bhaktivedanta Book Trust 1972, 68 p., available online at http://prabhupadabooks .com/pdf/Beyond_Birth_and_Death-Original_1974_edition_scan.pdf.

Prabhupada, A. C. Bhaktivedanta, Bhagavad-Gìtā As It Is, $2^{\text {nd }}$ ed., Los Angeles et al: The Bhaktivedanta Book Trust 1989, 924 p.

Prabhupada, A. C. Bhaktivedanta, Life Comes from Life (online), Bhaktivedanta Book Trust 1973, 137 p., available online at http://www.krishnapath.org/free-ebooks -audiobooks-of-srila-prabhupada/life-comes-from-life/.

Prabhupada, A. C. Bhaktivedanta, The Nectar of Devotion: The compl ete Science of Bhakti Yoga: A Summary Study of Śrīla Rūpa Gosvāmī’s Bhakti-rasāmrta-sindhu (online), The Bhaktivedanta Book Trust 1969, 502 p., available online at https:// ebooks.iskcondesiretree.com/pdf/Nectar_of_Devotion_with_Sanskrit/Nectar_of _Devotion_with_Sanskrit.pdf.

Prabhupada, A. C. Bhaktivedanta, The Science of Self-Realization (online), The Bhaktivedanta Book Trust 2008, 233 p., available online at http://www.krishnapath. org/free-ebooks-audiobooks-of-srila-prabhupada/the-science-of-self-realization/.

Prabhupada, A. C. Bhaktivedanta, Śrīmad Bhāgavatam canto 1-10 (online), The Bhaktivedanta Book Trust 1972, available online at https://krishna.org/srimad -bhagavatam-original-edition-pdf-download/.

"Prabhupada on Gurukul" (online), March 2018, available online at https://krishna.org /srila-prabhupada-on-gurukul/.

Rochford, E. Burke, "Education and Collective Identity: Public Schooling of Hare Krishna Youths", in Susan Palmer and Charlotte Hardman, Children in New Religions, New Brunswick, N. J.: Rutgers University Press, 1999, p. 29-50.

Rochford, E. Burke, "Family Development and Change in the Hare Krishna Movement", in James R. Lewis and Jesper Aagaard Petersen, Controversial New Religions, New York: Oxford University Press 2005, xii, p. 101-117.

RochFord, E. Burke, "Family Formation, Culture and Change in the Hare Krshna Movement”, ISKCON Communications Journal (2/1997): p. 61-82.

Rochford, E. Burke, and Jennifer Heinlein, "Child Abuse in the Hare Krishna Movement: 1971-1986”, ISKCON Communications Journal (1/1998): p. 43-69.

Rochford, E. Burke, The Hare Krishna in America, New Brunswick, N.J.: Rutgers University Press 1985, 324 p.

Rochford, E. Burke, The Hare Krishna Transformed, New York: New York University Press 2007, 285 p.

Satsvarupa Dasa Goswami, Prabhupada: Your Ever Well-Wisher, Los Angeles et al: The Bhaktivedanta Book Trust 1995, 370 p.

Schlichtsová, Jitka, “Pán Kršna a oddané děti”, Dingir (3/2013): p. 74-76.

New Govardhana Australia (online), accessed February 2016, available online at www .newgovardhana.net/gurukula.

Schlichtsová, JitKa, Výchova a vzdělání v hnutí Haré Kršna, unpublished M. A. thesis, Praha: Hussite Theological Faculty, Charles University 2013, 72 p.

"Schools" (online), ISKCON Ministry of Education, accessed February 2016, available online at http://iskconeducation.org/category/schools/.

Sri Mayapur International School (online), accessed January 2018, available online at www .mayapurschool.com.

ŠTamPaCH, Ivan O., "Problémy náboženské autority: Nalézt rovnováhu ve vztahu k autoritě" ["Problems with Religious Authority: Finding a Relationship with an Authority”], Dingir (1/1999), s. 14-15. 